\title{
Neospora caninum infection in Iran (2004-2020): A review
}

\author{
Jamal Gharekhani ${ }^{1,2}$ (i) $\cdot$ Mohammad Yakhchali $^{1} \cdot$ Reza Berahmat $^{3}$
}

Received: 23 May 2020/Accepted: 28 August 2020/Published online: 10 September 2020

(C) Indian Society for Parasitology 2020

\begin{abstract}
Knowledge on neosporosis and associated risk factors in different species of animals are so important for designing the control programs and reduce the economic losses globally. This literature review targeted for evaluating the infection rate of Neospora caninum in animals in Iran. Until April 2020, all of published documents in the main English and Persian-language databases were searched. A total number of 110 documents (English $=85$ and Persian $=25$ ) were extracted. Most of reports were seroepidemiological studies using ELISA in Iranian cattle population. The range of Neospora infection was $3.8-76.2 \%$ in cattle, $0-54.6 \%$ in dogs, $0.9-9.9 \%$ in sheep, $6.2 \%$ in goats, $19.2-55.9 \%$ in buffaloes, $20-42.2 \%$ in horses, $52 \%$ in donkeys, $3.2-27 \%$ in camels, $14 \%$ and $19 \%$ in cats, and $0-20.4 \%$ in rodents. This rate in birds was $17.3 \%$ in chicken, $9.8 \%$ and $30.4 \%$ in pigeons, $2.8 \%$ and $3.7 \%$ in sparrows, and $9.9 \%$ in hooded crows. This is a comprehensive literature review on Neospora infection in Iran at the first time. The infection of $N$. caninum is
\end{abstract}

Jamal Gharekhani

gharekhani_76@yahoo.com

Mohammad Yakhchali

m.yakhchali@urmia.ac.ir

Reza Berahmat

Berahmat156@gmail.com

1 Department of Pathobiology, Faculty of Veterinary Medicine, Urmia University, Urmia, Iran

2 Department of Laboratory Sciences, Central Veterinary Laboratory, Iranian Veterinary Organization, Hamedan Veterinary Office, Ayatollah-Rafsanjani Street, Hamedan 6519611156, Iran

3 Department of Parasitology, Faculty of Medicine, Tabriz University of Medical Sciences, Tabriz, Iran widespread in Iran especially in dogs and cattle population. This review can provide baseline information for future research. Study on other hosts especially on wild and exotic animals is recommended for exact estimate of neosporosis in Iran. Investigations into molecular diagnosis and genotyping of $N$. caninum strains are also needed; this will be helpful for developing vaccines and finding the connection among wild and domestic cycles of disease. Education on the risk factors associated with $N$. caninum infection for is suggested farmers and rural public.

Keywords Neospora caninum · Neosporosis · Animal · Bird · Risk factor $\cdot$ Review article $\cdot$ Iran

\section{Introduction}

Neospora caninum (Protozoa: Apicomplexa) is causative agent of neosporosis, a polysystemic parasitic disease with worldwide distribution (Dubey 2003). The parasite was isolated from five Boxer puppies with congenital encephalitis and myositis in Norway in 1984 for the first time (Bjerkas et al. 1984). Since then, $N$. caninum has been recognized as causative agent of abortion, stillbirth, and birth of weak neonates in several mammalian species, particularly cattle (Dubey et al. 2007).

Different species of canines such as domestic dogs (Canis familiaris), coyotes (C. latrans), dingoes ( $C$. domesticus), and gray wolves (C. lupus) are definitive hosts for $N$. caninum (Dubey et al. 2005). Based on data from parasite isolation as well as DNA and antibody detection, a wide range of domestic and wild ruminants, equids, camels, rodents, and avian species can serve as intermediate host of this parasite (Dubey and Schares 2011). 
Interestingly, dogs can be the definitive and intermediate host at the same time (Dubey et al. 2007).

Intermediate hosts become infected either via ingestion of oocysts with food and water (horizontal transmission), or via transplacental route (vertical transmission) (Dubey et al. 2005, 2007). In the intermediate host, oocysts transform in to motile and rapidly dividing tachyzoites, which subsequently change to bradyzoite which can localize in several tissues such as brain and muscles and form cysts. Upon consuming Neospora-tissue cysts by the definitive host, formation of oocysts in its intestine and its excretion in feces completes the life cycle (Dubey 2003).

In Iran, $N$. caninum infection was reported in dairy cattle from Mashhad, Northeast region at the first time (Sadrebazzaz et al. 2004). Since then, many epizootological studies have been conducted on various animals and avian species. However, there are no comprehensive reviews on the prevalence of $N$. caninum in Iran. Therefore, we aimed at collecting all the available information from 2004 to April 2020 to have a better picture of the situation in the country.

\section{Materials and methods}

\section{Introduction to the study area: Iran}

The country is located in western Asia between latitudes $24^{\circ}-40^{\circ} \mathrm{N}$, and longitudes $44^{\circ}-64^{\circ} \mathrm{E}$. It has an area of $1,648,195 \mathrm{~km}^{2}$ with different climatic regions: (1) Mediterranean in north on the coast of the Caspian Sea which is covered by the lush lowland and the vast forests, (2) continental and arid in the central plateau, (3) cold in mountains of west and northwest, and (4) desert and hot in the southeast (Fig. 1).

\section{Search criteria}

All peer reviewed documents published from 2004 to April 2020 in English-language databases (Google Scholar, Science Direct, Scopus PubMed and Proquest) and Persianlanguage databases (SID, Magiran, Iran Medex, and Iran Doc) were searched. The search terms which were used alone and/or combined included "Neospora," "Neospora caninum," "neosporosis," "epidemiology," "prevalence," "anti-Neospora antibodies," "animals," "cattle," "abortion," “dog," “sheep," "goat," "horse," “donkey," “cat," "bird," “chicken," “pigeon," “sparrow," “rodent," "camel," and "buffalo," "Iran." All of the enlisted terms were searched in Persian language too. Exclusion criteria were articles that had no data or insufficient data about prevalence and/or infection rate of Neospora.

\section{Results}

A total of 110 documents including 85 English and 25 Persian articles and theses were reviewed. Most of the papers was on cattle $(n=53)$ and $\operatorname{dogs}(n=25)$, respectively. The most of reports were sero-epidemiological studies using ELISA in Iranian cattle population. The range of Neospora infection was $3.8-76.2 \%$ in cattle, $0-54.6 \%$ in dogs, $0.9-9.9 \%$ in sheep, $6.2 \%$ in goats, $19.2-55.9 \%$ in buffaloes, $20-42.2 \%$ in horses, $52 \%$ in donkeys, $3.2-27 \%$ in camels, $14 \%$ and $19 \%$ in cats, and $0-20.4 \%$ in rodents. This rate in birds was $17.3 \%$ in chicken, $9.8 \%$ and $30.4 \%$ in pigeons, $2.8 \%$ and $3.7 \%$ in sparrows, and $9.9 \%$ in hooded crows. All of articles are summarized in Tables 1, 2, 3, 4, and 5 according to study regions, number and type of sample, method of examination, and gender.

\section{Discussion}

\section{Neospora caninum in cattle}

According to the latest report of Iranian Ministry of Agriculture (2019), overall cattle population in different regions of Iran is 1,202,000 in dairy farms, 4,616,000 in both beef and dairy farms and 2,271,000 of native breed in rural regions. The main raised breed is Holstein with a milk average production of $20 \mathrm{~L}$ per head/day. Also, the annually milk and meat production are estimated approximately 1,059,000 and 830 (×1000 Tons), respectively. The global median losses caused by abortions due to $N$. caninum are estimated of US\$1.3 billion annually (Reichel et al. 2013). Reichel et al. (2013) reported that 46.4 million cows were at annual risk of abortion. The economic losses were calculated to be US $\$ 1,600.00$ and US $\$ 150.00$ in the per dairy and beef farm, respectively (Reichel et al. 2013). Though many animals are involved in the life cycle of $N$. caninum, it is common between dog and cattle (Dubey et al. 2007). Most of Iranian researchers have concentrated on neosporosis in cattle; because of that's great impact on economic losses for farmers and also dairy industry. Vertical transmission is the most important infection route in cattle with frequency of $93.7 \%$ (Nicolino et al. 2017). Neosporosis in bovine has been related with endemic, epidemic and sporadic abortions, neonatal mortality, stillbirth, genitally infections, and decreasing of milk production (Guido et al. 2016). Most of the economic losses are associated with increase in the abortion rate, culling and decrease in the volume of milk production (Santos et al. 2016).

Wide range of infection is reported according to climate and geographic regions, type of samples (blood, milk, 


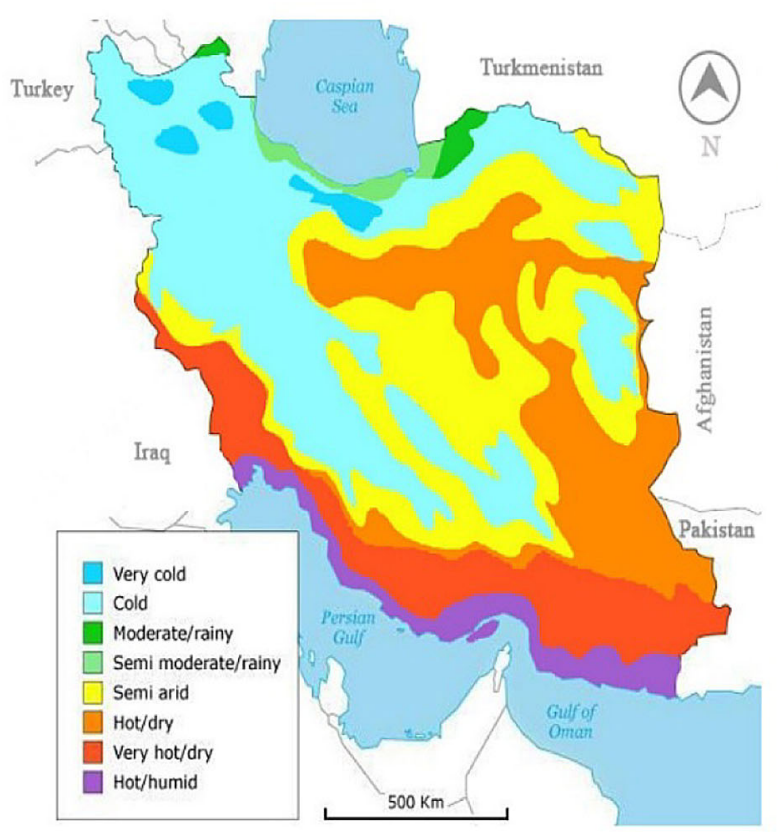

Fig. 1 The map of Iran with different geographic and climate regions

semen, and abortion material), type of animals (race, healthy, pregnant, and antecedents of abortion), and laboratory diagnostic techniques (Table 1). The global prevalence of $N$. caninum in cattle was calculated $20 \%(95 \%$ CI $18-21 \%$ ) by Ribeiro and colleagues (2019). They reported that seropositive cows were 1.6 times more likely to abort $(\mathrm{OR}=2.6)$ than seronegative ones. In a meta-analyses study from Iranian dairy cattle, overall seroprevalence is estimated $23.6 \%$ in limit scale on eligibility articles until September 2018 (Ansari-Lari 2020). In addition, seroprevalence rate showed significantly positive association with antecedents of abortion $(\mathrm{OR}=2.5)$ and studied regions, opposite to age and breed.

Dairy cattle were considered more susceptible to bovine neosporosis $(\mathrm{OR}=1.6)$ than beef cattle (Ribeiro et al. 2019). In Iran, the most reports of $N$. caninum infection were in dairy cattle with range of 3.8-76.2\% (Binaei 2016; Noori et al. 2019). The lowest infection rate $(3.8 \%)$ in Sistan is due to hot and dry climate in the region (Noori et al. 2019). Also, a high infection (57.3\%) in North of Iran is related to moderate and rainy climate, which is favorite for sporulation of oocysts (Youssefi et al. 2010). This rate was $10-95.2 \%$ in milk samples (Shakerian et al. 2015; Binaei 2016) and 7.4-10.5\% in semen samples (Sharifzadeh et al. 2012; Doosti et al. 2015). Bulk milk examination is using routinely for detection of antibodies to $N$. caninum in dairy farms due to ease of sampling, and the tests are cheap and rapid (Hurkova et al. 2005). 14.2\% and

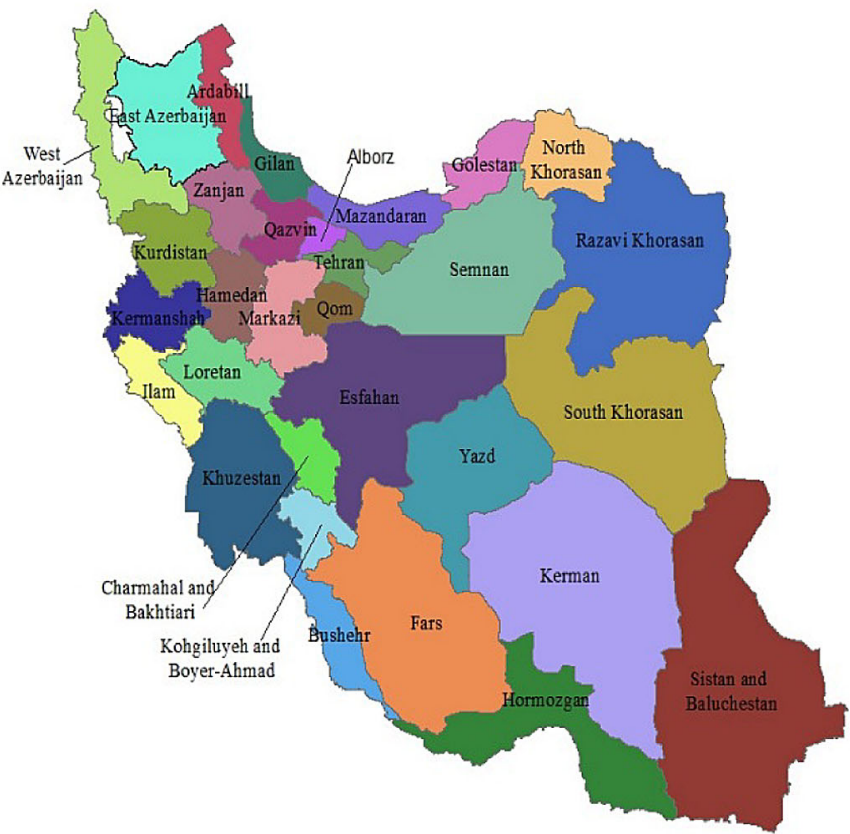

$20 \%$ of native cattle were seropositive in Hamedan district, West of Iran (Gharekhani et al. 2012; Gharekhani and Heidari 2014a). In pregnant cows, seroprevalence of $24.8 \%, 30.4 \%$, and $38.8 \%$ was reported in Hamedan, Shiraz, and Tehran, respectively (Salehi et al. 2010; Gharekhani and Yakhchali 2019). DNA of $N$. caninum is isolated in 11-66.7\% of aborted fetus materials using molecular techniques (Habibi et al. 2005; Rafati and Jafarian 2014). The seropositivity in pregnant cows is a risk factor for increase the abortion. According to De Meerschman et al. (2002) report, risk of abortion had a direct correlation with level of $N$. caninum-specific antibodies in the animals. The abortion risk in seropositive animals is estimated 1.6-26-fold higher than seronegative animals (Ribeiro et al. 2019).

Impact of age on seropositivity was variable, according to studied regions and also the reasons were not clear because of the various opinions. Razmi et al. (2006) and Gharekhani et al. (2013a) reported a significant correlation between seropositivity and age of animals $(P<0.05)$. Youssefi et al. (2010) found a significant increase in seropositivity in 4-5-year-old animals. Sadrebazzaz et al. (2004) reported equal levels of seroprevalence in all age groups for the most of the herds. Gharekhani and Heidari (2014a, b) opined that the increase of seroprevalence with age is related to sample size. On other hand, no significant correlation was seen between seropositivity and age by Nourollahifard et al. (2008), Gharekhani and Heidari 
Table 1 Infection rate of Neospora caninum in cattle population from different regions of Iran

\begin{tabular}{|c|c|c|c|c|c|c|}
\hline \multirow[t]{2}{*}{ Study area } & \multirow[t]{2}{*}{ Sample type } & \multirow[t]{2}{*}{ Methods } & \multicolumn{3}{|c|}{ No. of sample (positive \%) } & \multirow[t]{2}{*}{ References } \\
\hline & & & Total $(\%)$ & Male $(\%)$ & $\begin{array}{l}\text { Female } \\
(\%)\end{array}$ & \\
\hline Mashhad & Blood of dairy cattle & IFAT & $810(15.2)$ & & & $\begin{array}{l}\text { Sadrebazzaz et al. } \\
\text { (2004) }\end{array}$ \\
\hline Mashhad & Tissue of aborted fetuses & $\begin{array}{l}\text { Semi-nested } \\
\text { PCR }\end{array}$ & $6(66.7)$ & NA & NA & Habibi et al. (2005) \\
\hline Mashhad & Blood of dairy cattle & ELISA $^{\mathrm{a}}$ & $337(46.3)$ & & & Razmi et al. (2006) \\
\hline Mashhad & Brain of aborted fetuses & PCR & $100(13)$ & & & Razmi et al. (2007) \\
\hline \multirow[t]{2}{*}{ Mashhad } & $\begin{array}{l}\text { Sera and fluids of aborted } \\
\text { fetuses }\end{array}$ & IFAT & $12(50)$ & NA & NA & $\begin{array}{l}\text { Sadrebazzaz et al. } \\
\text { (2007) }\end{array}$ \\
\hline & Brain of aborted fetuses & $\begin{array}{l}\text { Semi-nested } \\
\text { PCR }\end{array}$ & $6(33)$ & & & \\
\hline \multirow[t]{2}{*}{ Mashhad } & Brain of aborted fetuses & PCR & $151(11.9)$ & & & Razmi et al. (2010) \\
\hline & fluids of aborted fetuses & ELISA $^{\mathrm{a}}$ & $151(9.9)$ & & & \\
\hline \multirow[t]{2}{*}{ Mashhad } & Blood of dairy cattle & ELISA $^{\mathrm{a}}$ & $200(19)$ & & & Razmi et al. (2013) \\
\hline & Brain of aborted fetuses & PCR & $200(11.5)$ & & & \\
\hline Mashhad & Blood of dairy cattle & ELISA $^{\mathrm{b}}$ & $116(24.3)$ & & & Mikhchi et al. (2013) \\
\hline Mashhad & Bulk milk & ELISA $^{\mathrm{c}}$ & $123(35)$ & & & $\begin{array}{l}\text { Razmi and Barati } \\
\text { (2017) }\end{array}$ \\
\hline $\begin{array}{l}\text { Neishabour, Khorasan Razavi } \\
\text { province }\end{array}$ & Blood of dairy cattle & ELISA $^{\mathrm{c}}$ & $250(18)$ & & & Atashgahi (2015) \\
\hline $\begin{array}{l}\text { Neishabour, Khorasan Razavi } \\
\text { province }\end{array}$ & Blood & ELISA $^{\mathrm{b}}$ & $100(26)$ & $9(22.22)$ & $91(26.3)$ & $\begin{array}{l}\text { Nourollahifard et al. } \\
\text { (2017) }\end{array}$ \\
\hline $\begin{array}{l}\text { Torbatheydariyeh, Khorasan Razavi } \\
\text { province }\end{array}$ & Blood of dairy cattle & ELISA $^{\mathrm{c}}$ & $280(16.1)$ & & & Shahidi (2016) \\
\hline Kerman province & Blood & ELISA $^{\mathrm{b}}$ & $285(12.6)$ & $98(10.2)$ & $\begin{array}{l}187 \\
(13.9)\end{array}$ & $\begin{array}{l}\text { Nourollahifard et al. } \\
\text { (2008) }\end{array}$ \\
\hline Shahrbabak, Kerman province & Blood of cattle & ELISA $^{\mathrm{a}}$ & $93(12.9)$ & $3(0)$ & $90(13.3)$ & Asadi (2016) \\
\hline Sirjan, Kerman province & Blood of dairy cattle & ELISA $^{\mathrm{c}}$ & $150(9.3)$ & & & Motamedipour (2016) \\
\hline Ahvaz & Blood & ELISA $^{\mathrm{a}}$ & $557(21)$ & NA & NA & Hajikolaei et al. (2008) \\
\hline Golestan province & Blood of dairy cattle & ELISA $^{\mathrm{a}}$ & $800(13.4)$ & & & Sattari et al. (2011) \\
\hline \multirow[t]{3}{*}{ Babol, Mazandaran province } & Blood of rural cattle & ELISA $^{\mathrm{a}}$ & $82(43.9)$ & NA & NA & Youssefi et al. (2009) \\
\hline & Blood of industrial cattle & & $155(25.8)$ & & & \\
\hline & Total & & $237(32)$ & & & \\
\hline Ardabil & Blood of cattle with abortion & ELISA $^{\mathrm{a}}$ & $46(7)$ & & & Youssefi et al. (2010) \\
\hline Garmsar, Semnan province & history & & $84(45.2)$ & & & \\
\hline Babol, Mazandaran province & & & $96(57.3)$ & & & \\
\hline Moghan, Ardabil province & $\begin{array}{l}\text { Different tissue of aborted } \\
\text { fetuses }\end{array}$ & PCR & $82(41.5)$ & & & Hoseini et al. (2018) \\
\hline Garmsar, Semnan province & Blood of dairy cattle & ELISA $^{\mathrm{a}}$ & $104(38.5)$ & & & $\begin{array}{l}\text { Ranjbarbahadori et al. } \\
\text { (2010) }\end{array}$ \\
\hline \multirow[t]{2}{*}{ Semnan } & Blood of dairy cattle & ELISA $^{\mathrm{b}}$ & $237(76.2)$ & & & Binaei (2016) \\
\hline & Milk of dairy cattle & & $104(95.2)$ & & & \\
\hline Tehran & Blood of pregnant dairy cattle & ELISA $^{\mathrm{a}}$ & $768(38.8)$ & & & Salehi et al. (2010) \\
\hline Tabriz & Blood of dairy cattle & ELISA $^{\mathrm{a}}$ & $266(10.5)$ & & & $\begin{array}{l}\text { Nematollahi et al. } \\
\text { (2011a) }\end{array}$ \\
\hline Tabriz & $\begin{array}{l}\text { Blood of cattle with abortion } \\
\text { history }\end{array}$ & ELISA $^{\mathrm{a}}$ & $32(20)$ & & & $\begin{array}{l}\text { Nematollahi et al. } \\
\text { (2011b) }\end{array}$ \\
\hline Tabriz & Blood of aborted cattle & ELISA $^{\mathrm{a}}$ & $76(18.4)$ & & & $\begin{array}{l}\text { Nematollahi et al. } \\
\text { (2013) }\end{array}$ \\
\hline
\end{tabular}


Table 1 continued

\begin{tabular}{|c|c|c|c|c|c|c|}
\hline \multirow[t]{2}{*}{ Study area } & \multirow[t]{2}{*}{ Sample type } & \multirow[t]{2}{*}{ Methods } & \multicolumn{3}{|c|}{ No. of sample (positive \%) } & \multirow[t]{2}{*}{ References } \\
\hline & & & Total $(\%)$ & Male $(\%)$ & $\begin{array}{l}\text { Female } \\
(\%)\end{array}$ & \\
\hline & Brain of aborted fetuses & PCR & $14(42.8)$ & & & \\
\hline East Azerbaijan province & Blood & ELISA $^{\mathrm{b}}$ & $236(17.8)$ & $74(10.8)$ & $162(20.9)$ & Gharedaghi (2012a) \\
\hline Hamedan & Blood of native cow & ELISA $^{\mathrm{a}}$ & $400(20)$ & & & Gharekhani et al. (2012) \\
\hline Hamedan province & $\begin{array}{l}\text { Blood of dairy cattle } \\
\text { Blood of beef cattle } \\
\text { Total }\end{array}$ & ELISA $^{\mathrm{a}}$ & $\begin{array}{r}492(12.8) \\
514(19.8) \\
1406(17.4)\end{array}$ & $\begin{array}{l}514 \\
\quad(19.8)\end{array}$ & $892(16)$ & $\begin{array}{l}\text { Gharekhani et al. (2014) } \\
\text { Gharekhani and Tavoosidana } \\
\text { (2013) } \\
\text { Gharekhani et al. (2013a) }\end{array}$ \\
\hline Hamedan province & Blood of aborted cattle & ELISA $^{\mathrm{a}}$ & $85(61.2)$ & & & Gharekhani (2014) \\
\hline Hamedan province & $\begin{array}{l}\text { Blood of pregnant dairy } \\
\text { cattle }\end{array}$ & ELISA $^{\mathrm{c}}$ & $476(24.8)$ & & & Gharekhani and Yakhchali (2019) \\
\hline Hamedan and Kurdistan & Blood of native cattle & ELISA $^{\mathrm{a}}$ & $768(14.2)$ & NA & NA & Gharekhani and Heidari (2014a) \\
\hline Kurdistan province & Blood of slaughtered cattle & ELISA $^{\mathrm{a}}$ & $368(7.8)$ & NA & NA & Heidari et al. (2014) \\
\hline Sanandaj & Blood of dairy cattle & ELISA $^{\mathrm{a}}$ & $336(17.6)$ & & & Adhami et al. (2014) \\
\hline Kermanshah & Blood of cattle & ELISA $^{\mathrm{c}}$ & $92(35.9)$ & NA & NA & Ghahvei (2014) \\
\hline Shahrekord & Blood of dairy cattle & ELISA $^{\mathrm{c}}$ & $184(28.3)$ & & & Fooroghi-Pardenjani (2013) \\
\hline Shahrekord & Brain of aborted fetuses & $\begin{array}{r}\text { Nested } \\
\text { PCR }\end{array}$ & $100(11)$ & & & Rafati and Jaafarian (2014) \\
\hline Shahrekord & Milk of rural cattle & PCR & $100(10)$ & & & Shakerian et al. (2015) \\
\hline Shahrekord & Milk from rural native cattle & $\begin{array}{r}\text { Nested } \\
\text { PCR }\end{array}$ & $100(24)$ & & & Alipour et al. (2018) \\
\hline Lorestan province & Blood of dairy cattle & ELISA $^{\mathrm{a}}$ & $347(9.8)$ & & & Nayebzadeh et al. (2015) \\
\hline Qom & Blood of dairy cattle & ELISA $^{\mathrm{c}}$ & $200(9)$ & & & Javanshir (2015) \\
\hline Isfahan province & Blood of dairy cattle & ELISA $^{\mathrm{a}}$ & $611(32.1)$ & & & Morovati and Noaman (2016) \\
\hline Isfahan province & Blood of dairy cattle & ELISA & $1500(26.3)$ & & & Hosseininejad et al. (2017) \\
\hline Kashan, Isfahan province & Milk from dairy cattle & ELISA $^{\mathrm{c}}$ & $187(18.2)$ & & & Hadadi et al. (2018) \\
\hline Isfahan province & Blood of dairy cattle & ELISA $^{\mathrm{a}}$ & $216(19)$ & & & Noaman and Nabinejad (2020) \\
\hline Shiraz & $\begin{array}{l}\text { Blood of pregnant dairy } \\
\text { cattle }\end{array}$ & ELISA $^{\mathrm{a}}$ & $253(30.4)$ & & & Ansari-Lari et al. (2017) \\
\hline \multirow[t]{2}{*}{ Fars province } & Blood of dairy cattle & ELISA & $180(32.1)$ & & & Tavanaee and Namavari (2017) \\
\hline & & NAT & $180(29.3)$ & & & \\
\hline $\begin{array}{l}\text { Shahriyar, Alborz } \\
\text { province }\end{array}$ & Milk from dairy cattle & ELISA $^{\mathrm{c}}$ & $150(22)$ & & & Taheri Lak et al. (2017) \\
\hline Arak & Brain of aborted fetuses & $\begin{array}{r}\text { Nested } \\
\text { PCR }\end{array}$ & $38(26.3)$ & & & Khani et al. (2018) \\
\hline Sistan region & Blood of dairy cattle & ELISA $^{\mathrm{c}}$ & $184(3.8)$ & & & Noori et al. (2019) \\
\hline \multirow[t]{2}{*}{ Different regions } & Fresh semen of Iranian bulls & PCR & $90(9.7)$ & & & Sharifzadeh et al. (2012) \\
\hline & $\begin{array}{l}\text { Frozen semen of Iranian } \\
\text { bulls }\end{array}$ & & $85(7.4)$ & & & \\
\hline Different regions & Brain of aborted fetuses & PCR & $395(45)$ & NA & NA & Kamali et al. (2014) \\
\hline Different regions & frozen semen & PCR & $57(10.5)$ & & & Doosti et al. (2015) \\
\hline
\end{tabular}

$a=\operatorname{IDEXX}^{\circledR}$ Company; $b=$ Svanova Biotech ${ }^{\circledR}$ Company; $c=$ ID-Vet ${ }^{\circledR}$ Company

NA not available, PCR polymerase chain reaction, NAT Neospora agglutination test, IFAT indirect fluorescent antibody test, ELISA enzymelinked immunosorbent assay

(2014a) and Heidari et al. (2014). Some researchers reported low seroprevalence in cattle of $>2 \mathrm{yr}$, which they found were due to decrease of antibodies in vertically transmitted infection (Dubey et al. 2007).
The high rate of seropositivity was determined in rural cattle $(20 \%)$ followed by beef $(19.8 \%)$ and dairy cattle $(12.8 \%)(P=0.004)$ (Gharekhani et al. 2013a). Gharekhani and Tavoosidana (2013) stated that $21.5 \%$ and $18.5 \%$ of animals with Hybrid and Holstein breed were seropositive, 
Table 2 Infection rate of Neospora caninum in dogs in different regions of Iran

\begin{tabular}{|c|c|c|c|c|c|c|}
\hline \multirow[t]{2}{*}{ Study area } & \multirow[t]{2}{*}{ Sample type } & \multirow[t]{2}{*}{ Methods } & \multicolumn{3}{|c|}{ No. of sample (positive $\%$ ) } & \multirow[t]{2}{*}{ References } \\
\hline & & & Total $(\%)$ & $\begin{array}{l}\text { Male } \\
(\%)\end{array}$ & $\begin{array}{l}\text { Female } \\
(\%)\end{array}$ & \\
\hline \multirow[t]{2}{*}{ Tehran } & Blood of farm dogs & IFAT & $50(46)$ & NA & NA & Malmasi et al. (2007) \\
\hline & Blood of household dogs & & $50(20)$ & NA & NA & \\
\hline \multirow[t]{2}{*}{ Tehran } & Blood of farm dogs & IFAT & $50(28)$ & NA & NA & Haddadzadeh et al. (2007) \\
\hline & Blood of urban dogs & & $53(11.3)$ & NA & NA & \\
\hline \multirow[t]{2}{*}{ Tehran } & Blood of stray dogs & ELISA $^{\mathrm{b}}$ & $42(2.2)$ & NA & NA & Pouramini et al. (2017) \\
\hline & Brain and other tissues & $\begin{array}{r}\text { Nested } \\
\text { PCR }\end{array}$ & $42(35.7)$ & 22 & $20(3)$ & \\
\hline \multirow[t]{2}{*}{ Mashhad } & Stool of household dogs & PCR & $85(0)$ & NA & NA & Razmi (2009) \\
\hline & Stool of farm dogs & & $89(2.2)$ & & & \\
\hline \multirow[t]{3}{*}{ Chaharmahal-va Bakhtiari } & Blood of stray dogs & IFAT & $50(46)$ & NA & NA & Hosseininejad et al. (2010a) \\
\hline & Blood of household dogs & & $50(20)$ & NA & NA & \\
\hline & Total & & $100(32)$ & NA & NA & \\
\hline Isfahan & $\begin{array}{l}\text { Blood of dogs referred to } \\
\text { clinic }\end{array}$ & IFAT & $233(10.3)$ & NA & NA & Hosseininejad et al. (2010b) \\
\hline Isfahan & Blood of farm dogs & IFAT & $113(17.7)$ & NA & NA & Hosseininejad et al. (2017) \\
\hline Isfahan & Stool of shelter dogs & $\begin{array}{r}\text { Nested } \\
\text { PCR }\end{array}$ & $90(24.4)$ & NA & NA & Motamedi et al. (2020) \\
\hline \multirow[t]{3}{*}{$\begin{array}{l}\text { Chaharmahal-va Bakhtiari, Isfahan and } \\
\text { Khuzestan }\end{array}$} & $\begin{array}{l}\text { Blood of stray or shepherd } \\
\text { dogs }\end{array}$ & ELISA & $317(43.3)$ & NA & NA & $\begin{array}{l}\text { Hosseininejad and Hosseini } \\
\text { (2011) }\end{array}$ \\
\hline & Blood of household dogs & & $231(8.7)$ & NA & NA & \\
\hline & Total & & $548(29.01)$ & $\begin{array}{l}300 \\
(29.3)\end{array}$ & $\begin{array}{l}248 \\
(28.6)\end{array}$ & \\
\hline Chaharmahal-va Bakhtiari province & Blood of dogs & IFAT & $200(27.5)$ & NA & NA & Raeisi (2010) \\
\hline Meshkin-Shahr (Ardabil) & Blood or rural dogs & ELISA & $171(30.4)$ & $\begin{array}{l}146 \\
(30.8)\end{array}$ & $25(28)$ & Sharifdini et al. (2011) \\
\hline Urmia & Blood of stray dogs & IFAT & $135(26.6)$ & $\begin{array}{l}81 \\
\quad(29.6)\end{array}$ & $54(22.2)$ & Yakhchali et al. (2010) \\
\hline Sarab (East Azerbaijan) & Blood or rural dogs & IFAT & $384(10.7)$ & $\begin{array}{l}306 \\
\quad(10.1)\end{array}$ & $78(12.8)$ & $\begin{array}{l}\text { Khanmohammadi and } \\
\text { Fallah (2011) }\end{array}$ \\
\hline Tabriz & Blood of stray dogs & IFAT & $100(31)$ & ${ }^{63}(33.3)$ & $37(27)$ & Gharedaghi (2012b) \\
\hline Tabriz & Stool of dogs & PCR & $100(21)$ & NA & NA & Fakheri (2019) \\
\hline \multirow[t]{2}{*}{ Shiraz } & $\begin{array}{l}\text { Blood of farm and } \\
\text { household dogs }\end{array}$ & MAT & $108(44.4)$ & ${ }^{64}(37.5)$ & $44(52.3)$ & Khordadmehr et al. (2012) \\
\hline & & $\begin{array}{l}\text { Dot- } \\
\text { ELISA }\end{array}$ & $108(54.6)$ & $64(50)$ & $44(61.4)$ & \\
\hline \multirow[t]{6}{*}{ Hamedan } & Blood of stray dogs & IFAT & $200(52.8)$ & NA & NA & Gharekhani et al. (2013a) \\
\hline & Blood of shepherd dogs & & $70(18)$ & NA & NA & \\
\hline & Total & & $270(27)$ & $\begin{array}{l}158 \\
(23.4)\end{array}$ & $\begin{array}{l}112 \\
\quad(32.1)\end{array}$ & \\
\hline & Blood of dairy farm dogs & ELISA $^{\mathrm{b}}$ & $185(8.6)$ & $\begin{array}{l}56 \\
(17.9)\end{array}$ & $129(4.7)$ & $\begin{array}{l}\text { Gharekhani and Yakhchali } \\
\text { (2019) }\end{array}$ \\
\hline & Blood of stray dogs & ELISA $^{\mathrm{b}}$ & $180(5)$ & $64(7.8)$ & $116(3.5)$ & $\begin{array}{l}\text { Gharekhani and Yakhchali } \\
\text { (2019) }\end{array}$ \\
\hline & Blood of pet dogs & & $184(4.9)$ & $79(1.3)$ & $105(7.6)$ & Gharekhani et al. (2020) \\
\hline Lorestan province & Stool of farm dogs & PCR & $428(2.1)$ & NA & NA & Dalimi et al. (2014) \\
\hline Qom & Blood of farm dogs & ELISA $^{\mathrm{b}}$ & $50(4)$ & NA & NA & Javanshir (2015) \\
\hline Ahvaz & $\begin{array}{l}\text { Blood of dogs referred to } \\
\text { clinic }\end{array}$ & ELISA & $100(18)$ & NA & NA & Hosseininejad et al. (2018) \\
\hline
\end{tabular}


Table 2 continued

\begin{tabular}{|c|c|c|c|c|c|c|}
\hline \multirow[t]{2}{*}{ Study area } & \multirow[t]{2}{*}{ Sample type } & \multirow[t]{2}{*}{ Methods } & \multicolumn{3}{|c|}{ No. of sample (positive \%) } & \multirow[t]{2}{*}{ References } \\
\hline & & & Total $(\%)$ & $\begin{array}{l}\text { Male } \\
(\%)\end{array}$ & $\begin{array}{l}\text { Female } \\
(\%)\end{array}$ & \\
\hline Ahvaz & $\begin{array}{l}\text { Blood of rural and urban } \\
\text { dogs }\end{array}$ & NAT & $150(20)$ & 85 (17) & $65(20)$ & Mosallanejad et al. (2018a) \\
\hline Different regions & Blood of stray dogs & IFAT & $137(12.4)$ & $\begin{array}{l}90 \\
\quad(16.7)\end{array}$ & $47(4.3)$ & Yakhchali et al. (2017) \\
\hline
\end{tabular}

$b=$ ID-Vet ${ }^{\circledR}$ Company

$N A$ not available, PCR polymerase chain reaction, NAT Neospora agglutination test, MAT modified agglutination test, IFAT indirect fluorescent antibody test, ELISA enzyme-linked immunosorbent assay

Table 3 Infection rate of Neospora caninum in sheep and goats from different regions of Iran

\begin{tabular}{|c|c|c|c|c|c|c|c|}
\hline \multirow{2}{*}{$\begin{array}{l}\text { Animal } \\
\text { type }\end{array}$} & \multirow[t]{2}{*}{ Study area } & \multirow[t]{2}{*}{ Sample type } & \multirow[t]{2}{*}{ Methods } & \multicolumn{3}{|c|}{ No. of sample (positive \%) } & \multirow[t]{2}{*}{ References } \\
\hline & & & & Total $(\%)$ & $\begin{array}{l}\text { Male } \\
(\%)\end{array}$ & $\begin{array}{l}\text { Female } \\
(\%)\end{array}$ & \\
\hline \multirow[t]{15}{*}{ Sheep } & \multirow[t]{3}{*}{ Aleshtar, Lorestan province } & Blood of aborted ewes & ELISA $^{\mathrm{b}}$ & $170(1.1)$ & & & Ezatpour et al. (2013) \\
\hline & & Blood of healthy ewes & & $410(1.7)$ & & & \\
\hline & & Total & & $586(1.5)$ & & & \\
\hline & \multirow[t]{2}{*}{ East Azerbaijan province } & Blood of aborted ewes & ELISA $^{\mathrm{a}}$ & $70(5.7)$ & & & Asadpour et al. (2013) \\
\hline & & Fetal tissue & PCR & $70(8.5)$ & & & \\
\hline & $\begin{array}{l}\text { Mianeh, East Azerbaijan } \\
\text { province }\end{array}$ & Blood & ELISA $^{\mathrm{c}}$ & 317 (4.1) & NA & NA & Vajdi et al. (2014) \\
\hline & \multirow[t]{4}{*}{ Tehran } & $\begin{array}{l}\text { Healthy slaughtered } \\
\text { sheep }\end{array}$ & $\begin{array}{l}\text { Nested } \\
\text { PCR }\end{array}$ & $317(2.5)$ & NA & NA & Arbabi et al. (2016) \\
\hline & & Heart & & $180(6.7)$ & & & \\
\hline & & Brain & & $150(0.7)$ & & & \\
\hline & & Total & & $330(3.9)$ & & & \\
\hline & Hamedan & Blood of aborted ewes & ELISA $^{\mathrm{a}}$ & $358(2.2)$ & & & $\begin{array}{l}\text { Gharekhani et al. } \\
\text { (2013b) }\end{array}$ \\
\hline & Golpayegan, Isfahan province & Blood of ewes & ELISA $^{\mathrm{b}}$ & $250(6.8)$ & & & Shahi (2016) \\
\hline & Mashhad & Fetal brain & PCR & $71(9.9)$ & NA & NA & $\begin{array}{l}\text { Razmi and Naseri } \\
\text { (2017) }\end{array}$ \\
\hline & Khuzestan province & Blood & ELISA $^{\mathrm{b}}$ & $550(6.8)$ & $163(6.1)$ & $392(7.1)$ & $\begin{array}{l}\text { Gharekhani et al. } \\
\text { (2018) }\end{array}$ \\
\hline & Different provinces & Fetal brain & $\begin{array}{l}\text { Semi- } \\
\text { nested } \\
\text { PCR }\end{array}$ & $109(0.9)$ & & & Sasani et al. (2013) \\
\hline \multirow[t]{2}{*}{ Goats } & Hamedan & Blood & ELISA $^{\mathrm{b}}$ & $450(6.2)$ & $54(11.1)$ & $396(5.6)$ & $\begin{array}{l}\text { Gharekhani et al. } \\
\text { (2016) }\end{array}$ \\
\hline & Khuzestan province & Blood & ELISA $^{\mathrm{b}}$ & $185(10.8)$ & $30(16.7)$ & $155(9.7)$ & $\begin{array}{l}\text { Gharekhani et al. } \\
\text { (2018) }\end{array}$ \\
\hline
\end{tabular}

$a=$ IDEXX $^{\circledR}$ Company; $b=$ ID-Vet $^{\circledR}$ Company; $c=$ VMRD $^{\circledR}$ Company

$N A$ not available, $P C R$ polymerase chain reaction, IFAT indirect fluorescent antibody test, ELISA enzyme-linked immunosorbent assay

respectively $(P>0.05)$. The high infection in dairy cattle as against beef cattle is related to different production systems for dairy and beef cattle. As few studies have been conducted on the animals breed, planning and conducting extensive researches on the association between various breed and infection is recommended.
Abortion is a predominant clinical sign of neosporosis in cattle (Dubey 2003). There is a direct association between the level of antibodies to $N$. caninum in cows and occurrence of abortion (De Meerschman et al. 2002). The risk of abortion due to neosporosis is estimated $14.3 \%$ in different regions (Reichel et al. 2013). In addition, the risk of 
Table 4 Infection rate of Neospora caninum (and/or Neospora sp.) in cats, camels, buffaloes, and equine population from different regions of Iran

\begin{tabular}{|c|c|c|c|c|c|c|c|}
\hline \multirow[t]{2}{*}{ Animal type } & \multirow[t]{2}{*}{ Study area } & \multirow[t]{2}{*}{ Sample type } & \multirow[t]{2}{*}{ Methods } & \multicolumn{3}{|c|}{ No. of sample (Positive \%) } & \multirow[t]{2}{*}{ References } \\
\hline & & & & Total $(\%)$ & Male $(\%)$ & $\begin{array}{l}\text { Female } \\
(\%)\end{array}$ & \\
\hline \multirow[t]{2}{*}{ Cat } & Ahvaz & Blood (feral cat) & NAT & $100(19)$ & $57(19.3)$ & 43 (18.6) & Hamidinejat et al. (2011a) \\
\hline & Ahvaz & $\begin{array}{l}\text { Blood (domestic } \\
\text { Persian cat) }\end{array}$ & NAT & $100(14)$ & $52(3.6)$ & $48(3.4)$ & Hamidinejat et al. (2011b) \\
\hline \multirow[t]{4}{*}{ Rodent } & Arak & $\begin{array}{l}\text { Brain tissue of } M u s \\
\quad \text { musculus }\end{array}$ & PCR & $68(0)$ & & & Khani (2016) \\
\hline & Ahvaz & Blood of Rattus rattus & NAT & $150(6)$ & $83(6)$ & $67(5.9)$ & $\begin{array}{l}\text { Mosallanejad et al. } \\
\quad(2018 b)\end{array}$ \\
\hline & Meshgin-Shahr & Brain tissue & PCR & $70(0)$ & $40(0)$ & $30(0)$ & Nazari et al. (2019) \\
\hline & Meshgin-Shahr & Blood & IFAT & $157(20.4)$ & $97(33)$ & $60(38.3)$ & Nazari et al. (2020) \\
\hline \multirow{4}{*}{$\begin{array}{l}\text { Camel (Camelus } \\
\text { dromedarius) }\end{array}$} & Mashhad & Blood (slaughterhouse) & IFAT & $120(5.8)$ & NA & NA & Sadrebazzaz et al. (2006) \\
\hline & Isfahan & Blood (slaughterhouse) & IFAT & $310(3.2)$ & NA & NA & $\begin{array}{l}\text { Hosseininejad et al. } \\
\text { (2009) }\end{array}$ \\
\hline & Yazd & Blood & NAT & $254(3.9)$ & $208(3.85)$ & $46(4.35)$ & Hamidinejat et al. (2013) \\
\hline & Bushehr & Blood & NAT & $92(27)$ & & & Namavari et al. (2017) \\
\hline \multirow[t]{6}{*}{ Buffalo (Bubalus bubalis) } & Ahvaz & Blood (slaughterhouse) & ELISA $^{\mathrm{a}}$ & $181(37)$ & $40(15)$ & $141(43.3)$ & Hajikolaei et al. (2007) \\
\hline & Ahvaz & Blood (slaughterhouse) & ELISA $^{\mathrm{a}}$ & $188(55.9)$ & $121(53.7)$ & $67(59.7)$ & Pourmahdi-Borujeni et al. \\
\hline & & & ELISA $^{\mathrm{b}}$ & & & & (2015) \\
\hline & & & NAT & & & & \\
\hline & Urmia & Blood (slaughterhouse) & ELISA & $83(19.2)$ & $32(3.6)$ & $51(15.6)$ & Rezvan et al. (2019) \\
\hline & & & $\begin{array}{c}\text { Nested } \\
\text { PCR }\end{array}$ & & & & \\
\hline \multirow[t]{7}{*}{ Horse (Equus caballus) } & Tabriz & Blood & MAT & $100(28)$ & NA & NA & Gharedaghi (2011) \\
\hline & Shiraz & Blood & MAT & $200(40)$ & $80(45)$ & $120(55)$ & Moraveji et al. (2011) \\
\hline & Mashhad & Blood & MAT & $150(30)$ & NA (55) & NA (45) & Hosseini et al. (2011) \\
\hline & Hamedan & $\begin{array}{l}\text { Blood of riding club } \\
\text { animals }\end{array}$ & MAT & $45(42.2)$ & $26(57.9)$ & $19(42.1)$ & Gharekhani et al. (2013c) \\
\hline & & Blood of rural animals & MAT & $75(40)$ & $17(52.9)$ & $58(36.2)$ & \\
\hline & & Total & MAT & $120(40.8)$ & $43(46.5)$ & $77(37.7)$ & \\
\hline & $\begin{array}{l}\text { Khuzestan } \\
\text { province }\end{array}$ & Blood of Arab breed & MAT & $235(20)$ & $122(16.4)$ & $113(23.9)$ & Tavalla et al. (2015) \\
\hline $\begin{array}{l}\text { Donkey (Equus africanus } \\
\text { asinus) }\end{array}$ & Hamedan & Blood & MAT & $100(52)$ & $22(36.1)$ & $78(56.4)$ & Gharekhani et al. (2013c) \\
\hline
\end{tabular}

$a=$ IDEXX $^{\circledR}$ Company; $b=$ ID-Vet $^{\circledR}$ Company

NA not available, PCR polymerase chain reaction, NAT Neospora agglutination test, MAT modified agglutination test, IFAT indirect fluorescent antibody test; ELISA Enzyme-linked immunosorbent assay

abortion in seropositive cows estimated 1.6-26 time higher than seronegative ones (Schares et al. 2004; Razmi et al. 2006; Ribeiro et al. 2019; Lefkaditis et al. 2020). Benavides et al. (2012) reported the risk of abortion in beef cattle is low compared to dairy cattle. Abortion rate associated with neosporosis in Iranian cows is reported between 7.8 and 66.7\% (Sadrebazzaz et al. 2004; Razmi et al. 2006; Salehi et al. 2010; Nematollahi et al. 2011a; Gharekhani et al. 2014; Ansari-Lari et al. 2017). By attention to AnsariLari et al. (2017) idea, up to $30 \%$ of abortions can be eliminated by control of $N$. caninum infection in the herd level.

In a study by Gharekhani and Heidari (2014a), 26\% of animals with history of abortion were seropositive $(P<0.0001$ and odds ratio $=2.9)$. Youssefi et al. $(2010)$ reported that $7 \%, 45.2 \%$ and $57.3 \%$ of aborted cattle were seropositive to N. caninum in Ardebil (Northwest of Iran, cold climate), Garmsar (Central of Iran, warm and dry climate) and Babol (North of Iran, rainy and mild climate), respectively. In a study from Northeast of Iran, the 
Table 5 Infection rate of Neospora caninum in birds from different regions of Iran

\begin{tabular}{llllll}
\hline Birds type & Study area & Sample type & Methods & No. of sample (positive\%) & References \\
\hline Chicken (Gallus domesticus) & Shiraz & Blood & MAT & $150(17.3)$ & Sayari et al. (2016) \\
Pigeon (Columba livia) & Ahvaz & Blood & NAT & $102(30.4)$ & Bahrami et al. (2016) \\
& & Brain tissue & PCR & $102(9.8)$ & Bahrami et al. (2015) \\
Sparrow (Passer domesticus) & Ahvaz & Brain tissue & PCR & $210(2.8)$ & Abdoli et al. (2015) \\
& Tehran & Brain tissue & Nested PCR & $217(3.7)$ & Abdoli et al. (2018) \\
hooded crows (Corvus cornix) & Tehran & Brain tissue & Nested PCR & $55(9.9)$ & .
\end{tabular}

$N A$ not available, $P C R$ polymerase chain reaction, NAT Neospora agglutination test, MAT modified agglutination test

prevalence of abortion in seropositive animals was reported higher than in seronegative $(P<0.05, \mathrm{OR}=1.78)$ ones (Razmi et al. 2006). Also, in the report of Hosseininejad et al. (2017), infection rate was detected significantly high in animals with history of abortion. Recently, a prospective cohort investigation in the country revealed that approximately $30 \%$ of abortions may be managed by control of $N$. caninum (Ansari-Lari et al. 2017). This is so important that the time is right to initiate vigorous inclusive efforts for preventing economic losses due to pathogen in Iran. The complication of $N$. caninum co-infections with other pathogens related with abortions can increase the rate of abortion. Noaman and Nabinejad (2020) found that, $N$. caninum plus bovine herpesvirus type 1 (BHV-1) co-infection was $12 \%$ versus $6.9 \%$ of $N$. caninum infection without BHV-1. Also, N. caninum seroprevalence was $10.7 \%$ and $8.5 \%$ in plus and without bovine viral diarrhea virus (BVDV) infection, respectively.

Gharekhani et al. (2014) reported that seroprevalence rate was $17.2 \%$ and $20.9 \%$ in farms with the presence of dog and also stray canids such as fox and jackal, respectively. In dairy farms, the seroprevalence rate had significant connection with history of abortion in individual level $(P=0.009)$, stillbirth $(P=0.02)$, and metritis in animals $(P=0.004)$, while no significant correlation was seen between stage of gestation $(P=0.977)$ and number of gestations $(P=0.986)$ in pregnant cows and also herd size $(P=0.178)$ with seropositivity of animals. Additionally, $33.7 \%$ of seropositive animals had history of artificial insemination $(P<0.0001)$ (Gharekhani and Yakhchali 2019). The risk of infection may increase with gestation, suggesting that horizontal transmission of $N$. caninum was particular importance in some herds with the presence of dog in farm (Dubey et al. 2007). Gharekhani et al. (2014) reported that the infection in dairy herds with $>100$ population was 2.7 -fold higher than $<100(P=0.0005)$. The number of dogs in each farm can be in direct relation with the herd size (Dubey and Schares 2011). Implementation of modern management with preventive approach inside the farms, and also farmers training is significantly effective for reducing the national economic losses due to bovine neosporosis.

\section{Neospora caninum in buffaloes}

Buffaloes, while being more susceptible to subclinical infection, are also more tolerant to neosporosis, and the inflammatory responses to infection are mild. Seroprevalence appears to be much higher in buffalo as compared to both dairy and beef cattle. Even when cattle and buffalo cohabit, thus sharing the same environmental risk factors, buffalo appears to show much higher infection rates. Abortions in buffalo seem infrequent in comparison with cattle (Reichel et al. 2015).

In Iran, buffalo breeding is traditional and limited in Southwest (Ahvaz) and Northwest (Urmia) regions. In the traditional condition, the chance of infection increase due to close contact with final hosts. Little is known about $N$. caninum infection in buffaloes in Iran and other countries. Reported seroprevalences are between $1.5 \%$ in Vietnam and $100 \%$ in Australia (Dubey et al. 2007), but the most differences are probably related to the different laboratory diagnostic tools. The overall seroprevalence is estimated $48 \%$ worldwide (Reichel et al. 2015). In a study (Hajikolaei et al. 2007), the seroprevalence of $N$. caninum was reported $37 \%$ in Ahvaz. There were significant differences between male (15\%) and female (43.3\%) animals. In females, $7.7 \%$ of heifers and $56.8 \%$ of cows were seropositive $(P<0.05)$. In another survey from Ahvaz, seroprevalence rate was $55.9 \%, 66.5 \%$, and $56.9 \%$ using different ELISA and also NAT techniques. No significant statistical differences were detected between seroprevalence rate, age, and sex of animals $(P>0.05)$ (PourmahdiBorujeni et al. 2015). Rezvan et al. (2019) found that in Urmia district, where all of seropositive samples (19.2\%) were confirmed using nested PCR for detection of Neospora NC5 gene, a $100 \%$ concurrency was detected among the high levels of anti-Neospora antibodies and parasitemia. The results indicated that the buffalo has no 
significant role in the cycle of disease in Iran because of low population in limit scale.

\section{Neospora caninum in dogs}

Dogs play a significant role for maintaining the infection and also occurrence of 'storms of abortions' due to horizontal transmission in dairy herds (Dubey et al. 2005, 2007). Adult infected dogs may represent various neuromuscular neurologic disorders. Pups are usually born without clinical signs. They typically show progression toward ascending paralysis of the rear limbs after 21 days of birth. In addition, paralysis of jaw, atrophy, dysphagia, and heart failure are gradually observed (Barber and Trees 1996). The presence of infected dog in dairy farms is a risk factor for herd population (Gharekhani and Yakhchali 2019; Ribeiro et al. 2019). Also, dogs commuting between farms and rural areas have an important impact in spreading of the infection. These factors are the possibility to consumption of cattle fetuses or placentas infected with tachyzoites or cysts of $N$. caninum, materials of aborted fetuses, or uterine discharge by dogs living in farm suburb (Haddadzadeh et al. 2007; Malmasi et al. 2007).

Infection to $N$. caninum was reported in range zero to $54.6 \%$ in different type of animals, samples, and diagnostic methods from Iran (Razmi 2009; Khordadmehr et al. 2012) (Table 2). This rate was varied from 1 to $100 \%$ throughout the world (Dubey and Schares 2011). Results of metaanalysis, the pooled seroprevalence was estimated $17.1 \%$ in global scale (Anvari et al. 2020) and also the infection rate was calculated to be higher in males $(15.8 \%)$, as compared to females (15.2\%).

The high risk of infection was seen in farm dogs with a close contact with seropositive animals and secreted materials. In the most of reports, a high infection was detected in stray dogs above 2 years old. This is due to their more probable of exposure to $N$. caninum infection and infected postnatally (Hossininejad and Hosseini 2011). Some of researchers stated that the highest infection is in male dogs (Malmasi et al. 2007; Yakhchali et al. 2010; Sharifdini et al. 2011). Most of the farmers tend to have male dogs in their farms. Therefore, the male dogs might have been more infectious than females (Malmasi et al. 2007; Khanmohammadi and Fallah 2011).

Study by Gharekhani et al. (2013a) found that $52.8 \%$ of stray dogs and $18 \%$ of shepherd dogs were seropositive $(P<0.001)$. Haddadzadeh et al. (2007) reported $28 \%$ and $11.3 \%$ of seropositivity in farm and urban dogs, respectively $(P=0.032)$. Additionally, antibodies to $N$. caninum in farm dogs $(46 \%)$ were higher than household dogs (20\%) $(P=0.005)$ (Malmasi et al. 2007). It was found that only one of the evaluated cases with antibodies titers of more than 1:800 in IFA technique had severe clinical signs of dermatitis and locomotion difficulties (Malmasi et al. 2007). Hosseininejad et al. (2010a) reported no statistical evaluation was possible to compare the infection rate and different breeds. Because of limited information on breed impact on $N$. caninum infection in dogs, focus on this subject in future investigations is essential.

Animals with latent disease and/or co-infection with other pathogens are high susceptible to $N$. caninum infection (Anvari et al. 2020). The simultaneous presence of $N$. caninum and T. gondii infections was detected in $2.8 \%$, $4 \%$, and $8.9 \%$ of dogs from Hamedan, Ahvaz, and other regions of Iran, respectively (Hosseininejad and Hosseini 2011; Hosseininejad et al. 2018; Gharekhani and Yakhchali 2019). Also, N. caninum and Leishmania infantum co-infection was $9.4 \%$ in Northwest of Iran (Sharifdini et al. 2011). Dogs are a matter of concern also to public health as a source of $N$. caninum infection. Accordingly, the preparation of a comprehensive information on $N$. caninum infection in dogs is necessary. It is suggested that researchers carry out further projects for blocking the neosporosis in dogs especially working on efficient vaccine.

\section{Neospora caninum in sheep and goats}

In Iran, most of the sheep and goat breeding farms are traditional, and animals have a direct contact especially with stray dogs. The clinical and economic reality of neosporosis in sheep and goats is unclear. The disease has been sporadically reported as a reason for reproductive failures such as abortion and neonatal mortality in these animals, similar to toxoplasmosis (Dubey and Schares 2011; Razmi and Naseri 2017). Two researches on neosporosis in goats were conducted in Iran by Gharekhani et al. (2016, Gharekhani et al. 2018a, b). In Hamedan, 6.2\% and $13.3 \%$ of examined animals were seropositive in individual and herd level, respectively. The infection was $5.8 \%$ in flocks with $30-99$ population and $23.7 \%$ in flocks with $100-300$ population $(P=0.013, \mathrm{OR}=5)$. The highest infection was significantly found in animals above 2 years of age $(54.4 \%, P=0.024$, $\mathrm{OR}=2.6)$. Also, $11.1 \%$ of male and $5.6 \%$ of females were seropositive $(P=0.112)$. This rate in animals with history of abortion $(60 \%)$ was 53 -fold higher than those without abortion $(P<0.0001)$ (Gharekhani et al. 2016). In Khuzestan province, $10.8 \%$ of goats and $32.4 \%$ of sheep flocks were positive for $N$. caninum and also the rate of mixed infection with $N$. caninum and $T$. gondii was 5.4\% (Gharekhani et al. 2018a, b). No significant correlation observed between sheep and goats $(P=0.082)$. Seropositivity in animals with history of abortion $(25 \%)$ was 3.6-time higher than others $(8.3 \%$, $P=0.022$ ). There were significantly high infection in $<1$ year-old animals $(25.9 \%)$ versus $1-2(15.8 \%)$ and $>2$ 
(5.8\%) age groups $(P=0.005)$. According to herd size, higher infection was in animals that sampled in herds with more than 500 populations $(P=0.016)$. No connection with gender was found (Table $3, P=0.330$ ).

The lowest and highest seroprevalence rate of $N$. caninum in sheep was reported $1.5 \%$ in Aleshtar (Lorestan province) and $6.8 \%$ in Golpayegan (Isfahan province), respectively (Table 3) (Ezatpour et al. 2013; Shahi 2016). Gharekhani et al. (2013b) reported $2.2 \%$ of seropositivity in aborted ewes in Hamedan. In addition, the significant difference was neither observed in different age groups $(P=0.999)$ nor between different fetal age groups $(P=0.671)$. In Ezatpour et al. (2013) work, no significant correlation was seen between seropositivity in aborted and healthy sheep from Aleshtar district $(P=0.516)$. Gharekhani et al. (2018a, b) reported the seropositivity in $6.8 \%$ of sheep and $37.8 \%$ of flocks in Khuzestan province. $N$. caninum and T. gondii co-infection was $3.2 \%$ in individual and $21.6 \%$ in herd levels. Population size in sheep flocks had a significant influence on seropositivity $(12.2 \%$ in < $250,1.7 \%$ in $250-500$ and $8.9 \%$ in $>500$ population; $P<0.0001)$ unlike to history of abortion $(P=0.094)$, age $(P=0.597)$, and sexes $(P=0.807)$ (Gharekhani et al. 2018a, b).

Histopathological examination in animals with neosporosis demonstrated extensive suppurative and nonsuppurative meningoencephalitis (Sasani et al. 2013). Along with various lesions incidence of cellular and vascular, the glial reactions were also assessed in aborted fetal brain tissues containing focal or diffuse gliosis by the authors. Some researchers (Asadpour et al. 2013; Sasani et al. 2013; Razmi and Naseri 2017) believe that neosporosis may act as a causative agent of abortion in sheep, as N. caninum DNA was isolated in $9.9 \%$ and $8.5 \%$ of brain samples derivate from aborted fetuses' in Mashhad and Tabriz regions, respectively. In investigations by Arbabi et al. (2016), DNA of $N$. caninum was detected in $6.7 \%$ and $0.7 \%$ of heart and brain samples, respectively, in animals without clinical signs.

\section{Neospora in equine}

Another species of Neospora, N. hughesi is considered as equine parasite. Abortion, protozoal myeloencephalitis, and neuromuscular disorder are the main findings of neosporosis in horses (Dubey and Schares 2011). Seroprevalence of Neospora infection was reported 20-40.8\% and $52 \%$ in horses and donkeys, respectively (Gharedaghi 2011; Hosseini et al. 2011; Moraveji et al. 2011; Gharekhani et al. 2013c; Tavalla et al. 2015). In a study by Gharekhani et al. (2013c), 42.2\% of riding club horses and $40 \%$ of rural horses from Hamedan were seropositive $(P=0.811)$; also, no significant connection was recognized among seropositivity, age and genders equivalent to other reports (Moraveji et al. 2011; Tavalla et al. 2015). The detail of published articles is demonstrated in Table 4 .

\section{Neospora caninum in camels}

Camel husbandry constitutes an important economic activity in the desert populations of the East, South, and Central regions of Iran (Fig. 1). According to the Iranian Veterinary Organization, average populations of 150,000 camels are reared in Iran. The camel is used as a load animal, playing a crucial role in transportation from rural areas. It is also a source of meat, skin, and leathers (Sadrebazzaz et al. 2006; Hosseininejad et al. 2009). The seroprevalence rate was detected as $3.2 \%$ and $3.9 \%$ in Isfahan and Yazd central regions of Iran (Hosseininejad et al. 2009; Hamidinejat et al. 2013), 5.8\% in Mashhad (Northwestern Iran) (Sadrebazzaz et al. 2006), and 27\% in Bushehr (South of Iran) (Namavari et al. 2017) (Table 4). Hamidinejat et al. (2013) reported that $3.85 \%$ of male animals and $4.35 \%$ of females were seropositive; in addition, this rate was $3.66 \%$ and $4.44 \%$ in animals living that hot-dry and cold-dry conditions. Data analyses revealed no statistical significant differences were seen between the seroprevalence of $N$. caninum in sex groups and different climates $(P>0.05)$. Many of the camel population is kept in communities lacking equipment and trained personnel for carrying out parasitological examinations; therefore, the development of rapid techniques for rapid detection of the main camel parasites such as $N$. caninum is essential.

\section{Neospora caninum in cats}

Cats are susceptible to $N$. caninum and can be infected both transplacentally and postnatally. The clinical aspects of Neospora infection are unclear in naturally infected animals (Dubey et al. 2007). Experimental infection has been reported in immunocompetent cats (Hamidinejat et al. 2011a). The presence of cats in the farms is a risk factor; as they have important role in the remaining of infection with eating the infected rodents (Dubey and Schares 2011). In Hamidinejat et al. (2011a, b) study from Ahvaz, 19\% of feral cats and $14 \%$ of domestic Persian cats were seropositive to $N$. caninum. There was no significant correlation between sex and seroprevalence rate (Table 4). Also, logistic regression showed that the prevalence rate increased significantly with age $(P<0.05)$. Available information confirmed that cats are the suitable intermediate hosts for $N$. caninum and may have a significant impact in epidemiology of the parasite (Dubey and Schares 2011). In the farm, cats become infected via consumption of cysts in rodents and also oocysts in environment (Donahoe et al. 2015). 


\section{Neospora caninum in rodents}

Rodents are one of the intermediate hosts for $N$. caninum and plays a significant role in continuity of parasite cycle (Dubey et al. 2007). The presence of rodents in dairy farms had a positive correlation with seroprevalence rate in cows and also is a risk factor for neosporosis in herd (Gharekhani and Yakhchali 2019). Yet, there are only four published papers on Neospora infection in Iranian rodents, only (Table 4). Mosallanejad et al. (2018b), working from Ahvaz, found antibodies to $N$. caninum in $6 \%$ of black rats (Rattus rattus). The seroprevalence rates were not significant statistically $(P<0.05)$ according to sexes. Brain tissues of 70 different rodent species (Persian jird (Meriones persicus): 50, gray dwarf hamster (Cricetulus migratorius): 9, and house mouse (Mus musculus): 11) were evaluated for $N$. caninum infection using molecular methods in Meshkin-Shahr district, Northwest Iran. All of the examined rodents were negative (Nazari et al. 2019) similar to Khani (2016), who investigated on $N$. caninum infection in rodents that were captured from dairy farms in Arak, Central Iran. In another research from Meshkin-Shahr by Nazari et al. (2020), antibodies to N. caninum were detected $12.9 \%$ in Persian jird, $20 \%$ in gray dwarf hamster, and $39 \%$ in house mouse using the indirect fluorescence antibody test (IFAT); a significant correlation $(P=0.002)$ was seen among the seroprevalence rate and different species of rodents. Interestingly, although low infection rates have been reported in rodents from Iran, there are some reports on notable infection in other countries such as Taiwan (16.4\%) and USA (10\%) (Huang et al. 2004; Hughes et al. 2006). In addition, $N$. caninum infection rate was recognized in $77 \%$ in house mouse, $71 \%$ in rock squirrel (Spermophilus variegatus), and 50\% in brown rat (Rattus norvegicus) from Mexico (Medina-Esparza et al. 2013). We recommended regular control of rodents to eliminate a potential reservoir of $N$. caninum infection in the farms.

\section{Neospora caninum in birds}

Neospora caninum antibodies and DNA were detected in different species of birds, but viable parasites have neither been demonstrated nor isolated by bioassays. Additionally, antibody responses to $N$. caninum were not persistent in experimentally infected birds (Dubey et al. 2007; Barros et al. 2018). None of the birds inoculated with tachyzoites developed clinical signs. It seems that chickens can be successfully infected with tachyzoites, but the host eliminates the infection. The role of birds in the life cycle of $N$. caninum is uncertain, but they may contribute to parasite transmission in sylvatic cycles either as mechanical vectors or as intermediate hosts (Barros et al. 2018).
There is little information on presence of $N$. caninum in birds in Iran and also in other countries (Abdoli et al. 2015; Barros et al. 2018). In Iran, N. caninum infection has been reported $2.8 \%$ and $3.7 \%$ in sparrows (Passer domesticus) (Abdoli et al. 2015; Bahrami et al. 2015), 17.3\% in chickens (Gallus domesticus) (Sayari et al. 2016), 9.8\% and $30.4 \%$ in Pigeons (Columba livia) (Bahrami et al. 2016), and $9.9 \%$ in hooded crows (Corvus cornix) (Table 5). The high infection in pigeons is probably related to the pigeon's diet. Pigeons commonly feed directly from the ground and are probably exposed to $N$. caninum after ingestion of the parasite oocysts from the soil (Bahrami et al. 2016). Bartels et al. (1999) reported a significant association between the presence and number of poultry with the increase of seroprevalence and abortion storms related to $N$. caninum in the farms. The occurrence of $N$. caninum infection in ground-foraging birds can be used to indicate environmental contamination with $N$. caninum oocysts (Abdoli et al. 2015). However, more research is needed to reveal the role of birds in the epidemiology of neosporosis.

\section{Neospora caninum in humans}

There is some information on neosporosis in humans worldwide. Various levels of $N$. caninum antibodies in immunodeficient humans are documented (Oshiro et al. 2015). In Lobato et al. (2006) study, antibodies to $N$. caninum were recognized $38 \%$ and $18 \%$ in HIV-infected patients and humans with neuro-psychological disorders, respectively, while this rate was $5 \%$ in newborns and $6 \%$ in healthy and normal man. In other hand, no antibodies were found in women with history of abortion (Petersen et al. 1999). Duarte et al. (2020) reported $24.3 \%$ of seropositivity for IgG anti-N. caninum in humans using IFAT; all of samples were negative for IgM. Also, $1 \%$ of umbilical cord blood samples were positive in molecular evaluation using Nc5 gene. No seen parasite-tissue cysts and/or inflammatory infiltration in histopathology. There was a significant connection $(P<0.05)$ among seroprevalence rate and the presence of dogs.

Neospora caninum has been successfully cultured in human cell lines, but that zoonotic aspect has not been defined yet (McCann et al. 2008). However, till date, no reports are available on this topic from Iran.

\section{Conclusion}

This research compiled the comprehensive information on Neospora infection in animals and birds in Iran for the first time. It is clear that $N$. caninum infection is distributed in wide scale from Iranian animals especially in cattle 
population. Both horizontal and vertical ways have an active role in transmission of the infection in this region. There are significant economic losses in Iranian dairy hers due to abortion, culling, and reproductive failures. This review can provide baseline information for future research. Study on other hosts, especially on wild and exotic animals, is recommended for exact estimate of neosporosis in Iran. Focus on molecular and genotyping diagnosis of $N$. caninum strains is needed; which will be helpful for developing vaccine and establish the link between wild and domestic cycles of disease. Public education on risk factors associated with $N$. caninum infection for farmers and rural people is suggested.

Acknowledgements The authors greatly appreciated to Prof. Hossein Hamidinejat and Dr. Alireza Sazmand for valuable comments and also Mrs. Kiani for designing the figure. The study was supported financially by Urmia University (a part of Ph.D. thesis), Urmia, Iran.

\section{Compliance with ethical standards}

Conflict of interest The authors declare that they have no conflict of interest.

Ethical approval The ethical guidelines have been consistence during the designing the project, date collection, and preparation of results. All of authors gave their informed consent prior to their inclusion in the research. We also hereby declare all ethical standards respected in the submitted article.

\section{References}

Abdoli A, Arbabi M, Dalimi A, Pirestani M (2015) Molecular detection of Neospora caninum in house sparrows (Passer domesticus) in Iran. Avian Pathol 44(4):319-322

Abdoli A, Arbabi M, Pirestani M, Mirzaghavami M, Ghaffarifar F, Dalimi A, Sadraei J (2018) Molecular assessment of Neospora caninum and Toxoplasma gondii in hooded crows (Corvus cornix) in Tehran. Iran. Com Immunol Microbiol Infec Dis 57:69-73

Adhami G, Hoghooghi R, Dalimi A (2014) The seroepidemiological investigation into Neospora caninum in cattle in Sanandaj, Kordestan Province. J Vet Microbiol 10(2):83-92 (in Persian)

Alipour M, Shakerian A, Rahimi E (2018) Prevalence of Toxoplasma gondii and Neospora caninum in different types of raw milk and traditional dairy product samples. J Food Saf 38(6):el2575

Ansari-Lari M (2020) Bovine neosporosis in Iran: a systematic review and meta-analysis. Prev Vet Med 176:104913

Ansari-Lari M, Rowshan A, Jesmani H, Masoudian M, Badkoobeh M (2017) Association of Neospora caninum with reproductive performance in dairy cows: a prospective study from Iran. Vet Res Forum 8(2):109-114

Anvari D, Saberi R, Sharif M, Sarvi S, Hosseini SB, Moosazadeh M, Hosseininejad Z, Nayeri Chegeni T, Daryani A (2020) Seroprevalence of Neospora caninum infection in dog population Worldwide: a systematic review and meta-analysis. Acta Parasitol 65:273-290

Arbabi M, Abdoli A, Dalimi A, Pirestani M (2016) Identification of latent neosporosis in sheep in Tehran, Iran by polymerase chain reaction using primers specific for the Nc-5 gene. Onderstepoort J Vet Res 83(1):1-7

Asadi M (2016) Seroprevalence of Neospora caninum infection in cattle from Shahrbabak. MSc thesis of Veterinary Parasitology, Veterinary School of Shahid bahonar University, Iran (in Persian)

Asadpour R, Jafari-Joozani R, Salehi N (2013) Detection of Neospora caninum in ovine abortion in Iran. J Parasitic Dis 37(1):105-109

Atashgahi S (2015) Seroprevalence of Neospora caninum infection in dairy cattle from Neishabour using ELISA. MSc thesis of Veterinary Parasitology, Veterinary School of Shahrekord University, Iran (in Persian)

Bahrami S, Hamidinejat H, Mayahi M, Baloutaki M (2015) A survey of Neospora caninum infection in sparrows (Passer domesticus) in Khuzestan province, Iran. Arch Razi Inst 70(4):279-281

Bahrami S, Boroomand Z, Alborzi A, Namavari M, Mousavi SB (2016) A molecular and serological study of Neospora caninum infection in pigeons from southwest Iran. Vet Arhive 86(6):815-823

Barros LD, Miura AC, Minutti AF, Vidotto O (2018) Neospora caninum in birds: a review. Parasitol Int 67:397-402

Benavides J, Katzer F, Maley S, Bartley P, Cantón G, PalareaAlbaladejo J, Purslow C, Pang Y, Rocchi M, Chianini F, Buxton D, Innes E (2012) High rate of transplacental infection and transmission of Neospora caninum following experimental challenge of cattle at day 210 of gestation. Vet Res 43:83

Binaei M (2016) Seroprevalence of Neospora caninum infection in dairy cattle from Semnan. DVM thesis, Veterinary School of Semnan University, Iran (No. 22) (in Persian)

Bjerkas I, Mohn SF, Presthus J (1984) Unidentified cyst-forming sporozoon causing encephalomyelitis and myositis in dogs. Zeitschrift für Parasitenkunde 70:271-274

Dalimi A, Sabevarinejad G, Ghafarifar F, Forouzandeh-Moghadam M (2014) Molecular detection of Neospora caninum from naturally infected dogs in Lorestan province, West of Iran. Arch Razi Inst 69(2):185-190

De Meerschman F, Speybroeck N, Berkvens D, Rettigner C, Focant C, Leclipteux T, Cassart D, Losson B (2002) Fetal infection with Neospora caninum in dairy and beef cattle in Belgium. Theriogenology 58:933-945

Donahoe SL, Lindsay SA, Krockenberger M, Phalen D, Šlapeta J (2015) A review of neosporosis and pathologic findings of Neospora caninum infection in wildlife. Int J Parasitol Parasit Wildl 4:216-238

Doosti A, Khamesipour F, Nekoei S, Lutvikadic I (2015) Survey for the presence of Neospora caninum in frozen bull's semen samples by PCR assay. Asia Pac J Trop Dis 5(1):7-12

Duarte PO, Oshiro LM, Zimmermann NP, Csordas BG, Dourado DM, Barros JC, Andreotti R (2020) Serological and molecular detection of Neospora caninum and Toxoplasma gondii in human umbilical cord blood and placental tissue samples. Sci Rep 10:9043

Dubey JP (2003) Review of Neospora caninum and neosporosis in animal. Korea J Parasitol 41(1):1-16

Dubey JP, Schares G (2011) Neosporosis in animals-The last five years. Vet Parasitol 180:90-108

Dubey JP, Knickman E, Greene CE (2005) Neonatal Neospora caninum infections in dogs. Acta Parasitol 50(2):176-179

Dubey JP, Schares G, Ortegamora LM (2007) Epidemiology and control of Neosporosis and N. caninum. Clin Microbiol Rev 20:323-369

Ezatpour B, Alirezaei M, Hassanvand A, Zibaei M, Azadpour M, Ebrahimzadeh F (2013) The first report of Neospora caninum prevalence in aborted and healthy sheep from West of Iran. Comp Clin Pathol 24(1):19-22 
Fakheri A (2019) Study on Neospora caninum infection in stool of dogs from Tabriz using Coproscopy and PCR. DVM thesis in Veterinary School of Tabriz University, Iran (in Persian)

Fooroghi-Pardenjani M (2013) Seroprevalence of Neospora caninum in dairy cattle from Shahrekord using ELISA. DVM thesis, Veterinary School of Shahrekord University, Iran (in Persian)

Ghahvei Y (2014) Seroprevalence of Neospora caninum infection in cattle from Kermanshah. MSc thesis of Veterinary Parasitology, Veterinary School of Shahid bahonar University, Iran (in Persian)

Gharedaghi Y (2011) Seroepidemiology of Neospora sp., in horses in East-Azerbaijan province of Iran. Res J Biol Sci 6(5):224-226

Gharedaghi Y (2012a) Seroepidemiology of Neospora caninum in cattle in East-Azerbaijan province, North-West Iran. J Anim Vet Adv 11(5):645-648

Gharedaghi Y (2012b) Seroprevalence of Neospora caninum in stray dogs of Tabriz Iran. J Anim Vet Adv 11(6):723-726

Gharekhani J (2014) Seroprevalence of Neospora caninum and Toxoplasma gondii infections in aborted cattle in Hamedan. Iran. J Adv Vet Anim Res 1(2):32-35

Gharekhani J, Heidari H (2014a) Detection of anti-Neospora caninum antibodies in Iranian native cattle. J Adv Vet Anim Res 1(4):228-231

Gharekhani J, Heidari H (2014b) Serology based comprehensive study of Neospora infection in domestic animals in Hamedan province, Iran. J Adv Vet Anim Res 1(3):119-124

Gharekhani J, Tavoosidana G (2013) Serological survey of Neospora caninum (Sarcocystidae) infection in beef cattle from western Iran. Sci Parasitol 14:95-98

Gharekhani J, Yakhchali Y (2019) Neospora caninum infection in dairy farms with history of abortion in West of Iran. Vet Anim Sci 8:100071

Gharekhani J, Heidari H, Akbarein H (2012) Seroepidemiology of Neospora caninum in Iranian native and crossbreed cattle: a cross sectional study. J Vet Res 67(4):325-329 (in Persian)

Gharekhani J, Tavoosidana G, Akbarein H (2013a) Serological study of Neospora caninum infection in dogs and cattle from West of Iran. Comp Clin Pathol 23(5):1203-1207

Gharekhani J, Tavoosidana GR, Naderisefat GR (2013b) Seroprevalence of Neospora infection in horses and donkeys in Hamedan province, Western Iran. Vet World 6(9):620-622

Gharekhani J, Tavoosidana GR, Zandieh M (2013c) Seroprevalence of Neospora caninum in sheep from western Iran. Vet World 6(10):709-710

Gharekhani J, Haddadzadeh H, Bahonar A (2014) Prevalence of immunoglobulin $\mathrm{G}(\mathrm{IgG})$ antibody to Neospora caninum in dairy cattle of Hamedan province, West of Iran. Vet Res Forum 5(2):149-152

Gharekhani J, Esmaeilnejad B, Rezaei H, Yakhchali M, Heidari H, Azhari M (2016) Prevalence of anti-Neospora caninum antibodies in Iranian goats. Annal Parasitol 62(2):111-114

Gharekhani J, Yakhchali M, Abbasi-Doulatshahi E (2018a) Barati E (2019) Seroprevalence of Neospora caninum and Toxoplasma gondii infections in stray dogs of Hamadan suburb, West of Iran. Avicenna J Clin Microbiol Infect 6(2):57-60

Gharekhani J, Yakhchali M, Esmaeilnejad B, Mardani K, Majidi G, Sohrabi A, Berahmat R, Alaei MH (2018b) Seroprevalence and risk factors of Neospora caninum and Toxoplasma gondii in small ruminants in Southwest of Iran. Arch Razi Inst 73(4):305-310

Gharekhani J, Yakhchali M, Khaltabadi-Farahani R (2020) Prevalence and risk factors associated to Neospora caninum (Apicomplexa: Toxoplasmatidae) in pet dogs from Hamadan, West of Iran, 2016. Avicenna J Clin Microbiol Infect 7(1):22-26
Guido S, Katzer F, Nanjiani I (2016) Serology based diagnostics for the control of bovine Neosporosis. Trend Parasitol 32(2):131-143

Habibi GR, Hashemi-Fesharki R, Sadrebazzaz A, Bozorgi S, Bordbar N (2005) Semi-Nested PCR for diagnosis of Neospora caninum infection in cattle. Arch Razi Inst 59:55-64

Hadadi MR, Sherafati R, Delavari M, Arbabi M, Gilasi HR, Abed A (2018) Evaluation of anti-Neospora caninum antibody presence in cow's milk in Kashan. Feyz 22(3):333-338 (in Persian)

Haddadzadeh H, Sadrebazzaz A, Malmasi A, Ardakani HT, Nia PK, Sadreshirazi N (2007) Seroprevalence of Neospora caninum infection in dogs from rural and urban environments in Tehran, Iran. Parasitol Res 101(6):1563-1565

Hajikolaei MRH, Goraninejad S, Hamidinejat H, Ghorbanpour M, Paryab R (2007) Occurrence of Neospora caninum antibodies in water buffaloes (Bubalus bubalis) from the South-western region of Iran. Bull Vet Instit Pulawy 51(2):233-235

Hajikolaei MH, Hamidinejat H, Ghorbanpoor M, Goraninejad S (2008) Serological study of Neospora caninum infection in cattle from Ahvaz area, Iran. Int J Vet Res 2(1):63-127

Hamidinejat H, Mosalanejad B, Avizeh R, Jalali R, Hosseini M, Ghorbanpour M, Namavari M (2011a) Neospora caninum and Toxoplasma gondii antibody prevalence in Ahvaz feral cats, Iran. Jundishapur J Microbiol 4(4):217-222

Hamidinejat H, Mosalanejad B, Jalalil MR, Avizeh R, Ghorbanpour M (2011b) Prevalence of Neospora caninum in domestic cats from Ahvaz. Iran. Parasite 1(10):8-9

Hamidinejat H, Ghorbanpour M, Rasooli A, Nouri M, Hekmatimoghaddam SH, Namavari MM, Pourmehdi-Borojeni M, Sazmand AR (2013) Occurrence of anti-Toxoplasma gondii and Neospora caninum antibodies in camels (Camelus dromedarius) in the center of Iran. Turkey J Vet Anim Sci 37:277-281

Heidari H, Mohammadzadeh A, Gharekhani J (2014) Seroprevalence of Neospora caninum in slaughtered native cattle in Kurdistan province, Iran. Vet Res Forum 5(1):69-72

Hoseini A, Merat E, Samani S, Soltan Nezhad S, Danandeh R (2018) Comparison of Neospora caninum infected tissues in aborted fetal bovine by PCR. J Vet Res 73(3):377-382 (in Persian)

Hosseini MH, Moraveji M, Tahamtan Y, Rahimian A, Mohammadi G, Namavari M (2011) Seroprevalence of Neospora spp. in horses in North-East of Iran, Iran. J Parasitol 6(2):64-68

Hosseininejad M, Hosseini F (2011) Seroprevalence of Neospora caninum and Toxoplasma gondii infection in dogs from West and Central parts of Iran using two indirect ELISA tests and assessment of associate risk factors, Iran. J Vet Res 12(1):46-51

Hosseininejad M, Pirali-Kheirabadi K, Hosseini F (2009) Seroprevalence of Neospora caninum infection in camels (Camelus dromedarius) in Isfahan province, Center of Iran. Iran J Parasitol 4(4):61-64

Hosseininejad M, Hosseini F, Mahzounieh M, Nafchi AR, Mosharraf M (2010a) Seroprevalence of Neospora caninum infection in dogs in Chaharmahal-va-Bakhtiari province, Iran. Comp Clin Pathol 19(3):269-270

Hosseininejad M, Hosseini F, Mosharraf M, Shahbaz S, Mahzounieh M, Schares G (2010b) Development of an indirect ELISA test using an affinity purified surface antigen (p38) for sero-diagnosis of canine Neospora caninum infection. Vet Parasitol 171(3):337-342

Hosseininejad M, Mahzounieh M, Shams Esfandabadi N (2017) Neospora caninum Suspects as one of the most important causes of abortion in large dairy farms in Isfahan, Iran. J Parasitol 12(3):408-412

Hosseininejad M, Hosseini F, Auobei S (2018) Seroprevalence of Neospora caninum and Toxoplasma gondii in dogs in Ahwaz, Iran. Vet Res Biol Prod 122:97-100 (in Persian) 
Huang CC, Yang VH, Watanabe Y (2004) Finding of Neospora caninum in the wild brown rat. Vet Res 35:283-290

Hughes JM, Williams RH, Morley EK (2006) The prevalence of Neospora caninum and co-infection with Toxoplasma gondii by PCR analysis in naturally occurring mammal population. Parasitology 132:29-36

Hurkova L, Halova D, Modry D (2005) The prevalence of Neospora caninum antibodies in bulk milk of dairy herds in the Czech Republic: a case report. Vet Med 50(12):549-552

Javanshir A (2015) Seroprevalence of Neospora caninum infection in dairy cattle and dogs from Qom using ELISA. MSc thesis in Veterinary School of Shahrekord University, Iran (in Persian)

Kamali A, Seifi HA, Movassaghi AR, Razmi GR, Naseri Z (2014) Histopathological and molecular study of Neospora caninum infection in bovine aborted fetuses. Asia Pac. J Trop Biomed 4(12):990-994

Khani M (2016) Molecular detection of Neospora caninum in aborted fetuses and rodents of cattle farms in Arak. MSc thesis of Veterinary Parasitology (No: 49), Veterinary School of Tehran University, Iran (in Persian)

Khani M, Arabkhazaeli F, Hosseini SD, Shayan P (2018) Molecular detection of Neospora caninum in aborted fetuses of cattle farms in Arak. J Vet Res 73(4):457-463

Khanmohammadi M, Fallah E (2011) Prevalence of Neospora caninum antibodies in shepherd dogs in Sarab district, EastAzerbaijan province, Iran. Afr J Microbiol Res 5(28):5062-5066

Khordadmehr M, Hosseini S, Mohsenifar E, Namavari M, Khordadmehr S (2012) Seroprevalence of Neospora caninum in farm and household dogs determined by ELISA. Online J Vet Res 16(4):172-181

Lefkaditis M, Mpairamoglou R, Sossidou A, Spanoudis K, Tsakiroglou M (2020) Neospora caninum, a potential cause of reproductive failure in dairy cows from Northern Greece. Vet Parasitol Reg Rep 19:100365

Lobato J, Silva DA, Mineo T, Amaral J, Silva Segundo G, Costa-Cruz JM, Ferreira MS, Borges A, Mineo JR (2006) Detection of Immunoglobulin $\mathrm{G}$ antibodies to Neospora caninum in humans: high seropositivity rates in patients who are infected by human immunodeficiency virus or have neurological disorders. Clin Vaccine Immunol 84-89(13):1

Malmasi A, Hosseininejad M, Haddadzadeh H, Badii A, Bahonar A (2007) Serologic study of anti-Neospora caninum antibodies in household dogs and dogs living in dairy and beef cattle farms in Tehran, Iran. Parasitol Res 100:1143-1145

McCann CM, Vyse AJ, Salmon RL (2008) Lack of serologic evidence of Neospora caninum in humans, England. Emerg Infect Dis 14(6):978-980

Medina-Esparza L, Macías L, Ramos-Parra M, Morales-Salinas E, Quezada T, Cruz-Vázquez C (2013) Frequency of infection by Neospora caninum in wild rodents associated with dairy farms in Aguascalientes, Mexico. Vet Parasitol 191(1-2):11-14

Mikhchi A, Jafarabadi GA, Torshizi ME (2013) Seroprevalence of Neospora caninum in Holstein dairy cattle in Northeast of Iran. Res Opin Anim Vet Sci 3(12):453-456

Moraveji M, Hosseini M, Amrabadi O, Rahimian A, Namazi F, Namavari M (2011) Seroprevalence of Neospora spp. in horses in South of Iran. Trop Biomed 28(3):514-517

Morovati H, Noaman V (2016) Seroepidemiology of Neospora caninum in dairy cattle farms with a history of abortion in Isfahan province, Iran. J Vet Sci Anim Husb 4(3):304

Mosallanejad B, Bahrami S, Hamidinejat H, Ghanavati S (2018a) A serological survey of Neospora caninum infection in urban and rural dogs in Ahvaz district, Southwest of Iran. Arch Razi Instt 73(3):215-221

Mosallanejad B, Razi Jalali MH, Hamidinejat H, Peighambari E (2018b) A serological survey on Neospora caninum infection in wild rats (Rattus rattus) in Ahvaz district, Iran. J Zoonos Dis 3(1):1-9

Motamedi A, Keihani P, Momtaz H (2020) Molecular detection of Neospora caninum in infected dogs of Isfahan, Iran. J Zoonotic Dis 4(1):35-42

Motamedipour S (2016) Seroprevalence of Neospora caninum in dairy cattle from Sirjan. MSc thesis of Veterinary Parasitology, Veterinary School of Shahrekord University, Iran (in Persian)

Namavari M, Tavanaei H, Abasifar A, Manavian M, Nikoo D (2017) High seroprevalence of Neospora caninum antibodies in Camels (Camelus dromedarius) in the South of Iran. Appl Anim Sci Res J 24:57-62 (in Persian)

Nayebzadeh H, Norollahi-Fard SR, Khalili M, Zakian N, Taati M (2015) Seroprevalence of Neospora caninum infection in dairy cattle in west of Iran. Istanb Vet J 41(2):162-166

Nazari N, Shojaee S, Mohebali M, Teimouri A, Ghadiri K, Raeghi S, Shiee MR, Azarakhsh Y, Bozorgomid A (2019) Toxoplasma gondii and Neospora caninum in brain tissue of rodents in NorthWest Iran. Vet Med Res Rep 10:223-227

Nazari N, Shojaee S, Salimi M, Mohebali M, Ahmadifard N, Hamzavi Y, Zarei Z, Farahmand-Rad R, Bozorgomid A, Heydarian P (2020) Serological survey of Neospora caninum and Toxoplasma gondii co-infection in rodent in Northwestern Iran. Iran J Parasitol 15(2):253-258

Nematollahi A, Jaafari R, Moghaddam G (2011a) Seroprevalence of Neospora caninum infection in dairy cattle in Tabriz, Northwest Iran. Iran J Parasitol 6(4):95-98

Nematollahi A, Jafari Jozani R, Zaboli N (2011b) Adaptation of DotElisa for serodiagnosis of Neospora caninum infestation in aborted cows. Global Vet 7(2):149-152

Nematollahi A, Moghaddam G, Jaafari R, Helan JA, Norouzi M (2013) Study on outbreak of Neospora caninum-associated abortion in dairy cows in Tabriz (Northwest Iran) by serological, molecular and histopathologic methods. Asia Pac J Trop Med 6(12):942-946

Nicolino RR, Oliveira CS, Lopes LB (2017) Prevalence and risk factors associated with anti-Neospora caninum antibodies in dairy herds in the central region of Minas Gerais state, Brazil. Vet Parasitol: Reg Study Rep 10:71-74

Noaman V, Nabinejad A (2020) Seroprevalence and risk factors assessment of the three main infectious agents associated with abortion in dairy cattle in Isfahan province, Iran. Trop Anim Heal Prod. https://doi.org/10.1007/s11250-020-02207-8

Noori M, Rasekh M, Ganjali M, Nourollahi-Fard SR (2019) Seroprevalence of Neospora caninum infection and associated risk factors in cattle of Sistan areas, Southeastern Iran in 2016. Iran J Parasitol 14(2):340-346

Norollahifard SR, Khalili M, Fazli O, Sharifi H, Radfar MH (2017) Seroprevalence of Neospora caninum in cattle of Neishabour, Northeast Iran. Slovenian Vet Res 54(1):5-9

Nourollahifard SR, Khalili M, Aminzadeh A (2008) Prevalence of antibodies to Neospora caninum in cattle in Kerman province, South East Iran. Vet Arhive 78(3):253-259

Oshiro LM, Motta-Castro AR, Freitas SZ, Cunha RC, Dittrich RL Meirelles AC (2015) Neospora caninum and Toxoplasma gondii serodiagnosis in human immunodeficiency virus carriers. J Brazil Trop Med 48:568-572

Petersen E, Lebech M, Jensen L, Lind P, Rask M, Bagger P, Björkman C, Uggla A (1999) Neospora caninum infection and repeated abortions in Humans. Emerg Infec Dis 5(2):278-280

Pouramini A, Jamshidi S, Shayan P, Ebrahimzadeh E, Namavari M, Shirian S (2017) Molecular and serological detection of Neospora caninum in multiple tissues and CSF in asymptomatic infected stray dogs. Iran J Vet Med 11(2):105-112

Pourmahdi-Borujeni M, Hamidinejat H, Ghorbanpour M, Asefi H (2015) Comparison of serological methods for the diagnosis of 
Neospora caninum infection in water buffalo (Bubalus bubalis). J Vet Microbiol 11(1):19-26 (in Persian)

Raeisi A (2010) Seroprevalence of Neospora caninum infection in dogs from Chaharmahal-va-Bakhtiari province using IFA. Ph.D thesis in Veterinary School of Shahrekord University, Iran (in Persian)

Rafati N, Jaafarian M (2014) The determination of prevalence of in aborted fetuses in dairy cattle of Shahrekord area, Chaharmahalva Bakhtiari province, by Nested-PCR. J Vet Lab Res 6(1):45-50 (in Persian)

Ranjbarbahadori S, Motevaselian A, Bokaie S, Yousefi M (2010) Serological study of Neospora caninum in aborted dairy cattle in Garmsar, Iran. Comp Biopathol 2:249-254 (in Persian)

Razmi GR (2009) Fecal and molecular survey of Neospora caninum in farm and household dogs in Mashhad area, Khorasan province, Iran. Korea J Parasitol 47(4):417-420

Razmi G, Barati M (2017) Prevalence of Neospora caninum and Toxoplasma gondii antibodies in bulk milk of dairy cattle, Mashhad, Iran. Arch Razi Inst 72(3):265-269

Razmi GR, Naseri Z (2017) Molecular detection of Neospora caninum infection in ovine aborted foetuses in the Mashhad area, Iran. Annal Parasitol 63(1):45-47

Razmi GR, Mohammadi GR, Garrosi T, Farzaneh N, Fallah A, Maleki M (2006) Seroepidemiology of Neospora caninum infection in dairy cattle herds in Mashhad area. Iran. Vet Parasitol 135(2):187-189

Razmi GR, Maleki M, Farzaneh N, Garoussi MT, Fallah A (2007) First report of Neospora caninum-associated bovine abortion in Mashhad area, Iran. Parasitol Res 100(4):755-757

Razmi GR, Zarea H, Naseri Z (2010) A survey of Neospora caninumassociated bovine abortion in large dairy farms of Mashhad, Iran. Parasitol Res 106:1419-1423

Razmi GR, Zarae H, Norbakhsh MF, Naseri Z (2013) Estimating the rate of transplacental transmission of Neospora caninum to aborted fetuses in seropositive dams in Mashhad area, Iran. Iran J Vet Med 7(4):253-256

Reichel MP, Ayanegui-Alcérreca MA, Gondim LFP, Ellis JT (2013) What is the global economic impact of Neospora caninum in cattle - the billion-dollar question? Int J Parasitol 43:133-142

Reichel MP, McAllister MM, Nasir A, Moore DP (2015) A review of Neospora caninum in Water buffalo (Bubalus bubalis). Vet Parasitol 212:75-79

Rezvan H, Khaki A, Namavari M, Abedizadeh R (2019) An investigation of the concurrency of anti-Neospora antibody and parasitemia in water buffalo (Bubalus bubalis) in Northwest of Iran. Vet Res Forum 10(1):79-84

Ribeiro CM, Soares I, Mendes R, Bastos P, Katagiri S, Zavilenski R, Abreu H, Afreixo V (2019) Meta-analysis of the prevalence and risk factors associated with bovine neosporosis. Trop Anim Heal Prod 51(7):1783-1800

Sadrebazzaz A, Haddadzadeh H, Esmailnia K, Habibi G, Vojgani M, Hashemifesharaki R (2004) Serological prevalence of Neospora caninum in healthy and aborted dairy cattle in Mashhad, Iran. Vet Parasitol 124(3):201-204

Sadrebazzaz A, Haddadzadeh H, Shayan P (2006) Seroprevalence of Neospora caninum and Toxoplasma gondii in camels (Camelus dromedarius) in Mashhad, Iran. Parasitol Res 98(6):600-601

Sadrebazzaz A, Habibi G, Haddadzadeh H, Ashrafi J (2007) Evaluation of bovine abortion associated with Neospora caninum by different diagnostic techniques in Mashhad, Iran. Parasitol Res 100(6):1257-1260

Salehi N, Haddadzadeh HR, Shayan P, Vojgani M, Bolorchi M (2010) Serological study of Neospora caninum in pregnant dairy cattle in Tehran, Iran. Int J Vet Res 4(2):113-116

Santos T, Simões R, Mateus T, Lopes A (2016) Updates on Neospora caninum - economic impact. Exp Pathol Heal Sci 8(1):49-50
Sasani F, Javanbakht J, Seifori P, Fathi S, Hassan MA (2013) Neospora caninum as causative agent of ovine encephalitis in Iran. Pathol Discovery 1(1):1-5

Sattari A, Moshiri F, Musavi S (2011) The seroprevalence of Neospora caninum antibodies in dairy cattle herds in Golestan province, Iran. J Vet Microbiol 7(1):60-64

Sayari M, Namavari M, Mojaver S (2016) Seroprevalence of Neospora caninum infection in free ranging Chickens (Gallus domesticus). J Parasitic Dis 40(3):845-847

Schares G, Bärwald A, Staubach C (2004) Potential risk factors for bovine Neospora caninum infection in Germany are not under the control of the farmers. Parasitol 129:301-309

Shahi M (2016) Seroprevalence of Neospora caninum infection in ewes from Golpayegan using ELISA. MSc thesis of Veterinary Parasitology, Veterinary School of Shahrekord University, Iran (in Persian)

Shahidi M (2016) Study on abortions associated to Neospora caninum and congenital transmission in industrial dairy cattle from Torbat Heydariyeh. MSc thesis of Veterinary Parasitology, Veterinary School of Ferdowsi University, Iran (in Persian)

Shakerian A, Sherafati R, Rafati N, Sharifzadeh A (2015) Detection of Neospora caninum in raw milk of cattle in Shahrekord Using PCR. J Trop Infect Dis 70:9-14 (in Persian)

Sharifdini M, Mohebali M, Keshavarz H, Hosseininejad M, Hajjaran H, Akhoundi B, Foroushani AR, Zarei Z, Charehdar S (2011) Neospora caninum and Leishmania infantum co-infection in domestic dogs (Canis familiaris) in Meshkin-shahr district, Northwestern Iran. J Arthropod-Borne Dis 1(3):60-68

Sharifzadeh A, Doosti A, Dehkordi PG (2012) PCR assay for detection of Neospora caninum in fresh and frozen semen specimens of Iranian bulls. World App Sci J 17:742-749

Taheri Lak K, Sadraeii J, Dalimi A (2017) Prevalence of antibodies to Neospora caninum in milk samples from dairy farms in the Shahriyar. Vet J (Pajouhesh \& Sazandegi) 115:142-146 (in Persian)

Tavalla M, Sabaghan M, Abdizadeh R, Khademvatan S, Rafiei A, Piranshahi AR (2015) Seroprevalence of Toxoplasma gondii and Neospora spp. infections in Arab horses, Southwest of Iran. Jundishapur J Microbiol 8(3):e14939

Tavanaee HR, Namavari M (2017) Evaluation of attenuated variety of Neospora caninum for diagnosis of infection in cattle by agglutination test. Vet J (Pajouhesh \& Sazandegi) 115:153-157 (in Persian)

Vajdi HR, Khanmohammadi M, Moniri SM (2014) Seroprevalance of Neospora caninum in Miyaneh sheep (Azarbayejan-e-Sharghi province) by competitive ELISA and IFA methods. J Clin Large Anim 7(1):59-66 (in Persian)

Yakhchali M, Javadi S, Morshedi A (2010) Prevalence of antibodies to Neospora caninum in stray dogs of Urmia, Iran. Parasitol Res 106:1455-1458

Yakhchali M, Bahrami M, Asri-Rezaei S, Bokaie S (2017) The enzymes and electrolytes profiles in sera of Iranian stray dogs naturally infected with Neospora caninum. Annal Parasitol 63(1):63-68

Youssefi MR, Arabkhazaeli F, Tabar Molla H (2009) Seroprevalence of Neospora caninum infection in rural and industrial cattle in Northern Iran. Iran J Parasitol 4(1):15-18

Youssefi MR, Ebrahimpour S, Esfandiari B (2010) Survey of Neospora caninum antibody in aborting cattle from three climate regions of Iran. World App Sci J 10:1448-1451

Publisher's Note Springer Nature remains neutral with regard to jurisdictional claims in published maps and institutional affiliations. 